\title{
Road to a New Self: Urban Environment in the Reimagination of a Migrant's Identity in Gimme the Money by Iva Pekarkova*
}

\begin{abstract}
There is no other place in the world where the impact of migration is more vivid than in the streets of New York City, which is often considered to be one of the greatest cultural centers, that has been welcoming immigrants from all over the world. It is precisely them, labourers, business owners, taxi drivers, who by being the essential part of New York City's diversity are constantly redefining its identity and whose own identities are being transformed and reimagined through the interaction with the city. In Gimme the Money Iva Pekarkova turns to New York City in order to show the immigrant identity as an identity in movement by making a leading character cruising around the city as a cab lady and by referring to the city both as to the exterior setting and the interior landscape of the leading character's mind. The paper will offer the analysis of the personal transformation of the heroine, who because of the persistent sense of dislocation and constant observation of the city reimagines herself by relating to New York City's streets and by becoming the part of the community of urban residents finds herself a new home.
\end{abstract}

Keywords: migration, identity, mental map, flâneuse, psychogeography

"There is only one New York, especially when it comes to immigration", 1 says Nancy Foner, a distinguished professor of sociology in Graduate Center and Hunter College, CUNY. New York City is America's classic immigrant city, which has its long immigration history, densely populated immigrant neighborhoods, cultural and linguistic diversity. Throughout the years, New York City has

*I thank the anonymous reviewer whose valuable remarks and comments have greatly improved this article.

${ }^{1}$ N. Foner, New York: A Unique Immigrant City, Newsletter of the American Sociological Association, http://www.asanet.org/sites/default/files/savvy/footnotes/indexone.html (access: 11.03.2019). 
been a major point of entry for immigrants and, as local studies suggest, this socially and culturally diverse place is more likely to adapt well to new migration, to be more inclusive, and to foster a positive integration for migrants, ${ }^{2}$ so it is no exaggeration to say that New York is accustomed to immigration.

The Annual Report of Mayor's Office of Immigrant Affairs of New York City (published in March 2018) says:

New York City is home to 3.1 million immigrants, the largest number in the City's history. Immigrants comprise nearly $38 \%$ of the city population and $45 \%$ of its workforce [...]. New York City is also home to approximately 560,000 undocumented immigrants [...]. Approximately $62 \%$ of New Yorkers live in households with at least one immigrant, including approximately one million New Yorkers who live in mixed-status households (where at least one person is undocumented). ${ }^{3}$

In this context, Gimme the Money, the novel by Iva Pekarkova, becomes a vivid literary representation of the contemporary migration crisis, when a "taxi story", 4 as the author calls it herself, becomes an eloquent narration of the existing reality. Many contemporary writers such as Mo Mason, Graham Russell Gao Hodges, Dmitry Samarov, and others refer to a taxi story as to the most effective means of reimagining a personality at the wheel and defining social interactions appearing in this context. Film directors also find this genre expressive when it comes to the exploration of the human nature and social bonds. For example, "Taxi Driver" by Martin Scorsese investigates a personality of a taxi driver, who, even though is alienated from society and cannot establish normal relationships with people, cares about the city he lives in and tries to change it in his own way. Later Jim Jarmusch in his "Night on Earth" by presenting a set of five episodes from taxi drivers' lives happening on the same night in different cities around the world, explores relationships between a taxi driver and a passenger and shows how regardless of all the differences their social experiences intertwine. Iva Pekarkova, for her part, in Gimme the Money within the frame of a literary taxi story reveals the complex nature of a migrant's identity formation and self-definition and explores to what extent social and urban environments determine the sense of belonging. Based on a true immigrant experience of the author, the novel manages to portray the reality, which any immigrant faces, without embellishing and literary figment. In this case, New York (the City; capitalized in the novel), presented through the leading character's eyes, is not only a reference point for a routine set of actions and moves, but also a medium in her search for a new self.

The main goal of this article is to analyse the role of the city as one of the most influential factors in the leading character's immigrant life, which defines her attitude, self-perception, and worldview, from different perspectives. In this

${ }^{2}$ D. Phillips, D. Robinson, Reflection on Migration, Community, and Place, "Population, Space and Place" 2003, nr 21 (5), p. 415.

${ }^{3}$ NYC Mayor's Office of Immigrant Affairs, State of Our Immigrant City. Annual Report, NYC Mayor's Office of Immigrant Affairs, https://www 1.nyc.gov/assets/immigrants/downloads/pdf/moia annual_report\%202019_final.pdf (access: 13.03.2019).

${ }^{4} \bar{V}$. Eliasova, A Cab of Her Own: Immigration and Mobility in Iva Pekarkova's Gimme the Money, “Contemporary Literature" 2006, nr 47 (4), p. 637. 
case physical, symbolic, and urban nature of visual imagery of the city presented in the novel will be explored with the help of the theory of urban experience, flânerie, and psychogeography. Kevin Lynch's profound and thoughtful observations about the interrelation between a clear environmental image of a city and emotional well-being of an individual in The Image of the City made it possible to better understand the visual and symbolic imagery of New York in the novel, analyse the leading character's urban experience with the help of a mental map concept and draw conclusions about reciprocal nature of interactions between the city and its inhabitants. Vera Eliasova's approach to the book as to a "nostalgiafree novel", presented in her article $A$ Cab of Her Own: Immigration and Mobility in Iva Pekarkova's "Gimme the Money", made it possible to reimagine a contemporary migrant's identity without a constant reference to the past. Instead, the researcher's detailed analysis of two essential features of the leading heroine's urban experience such as dynamism and mobility focuses readers' attention on the present as the only timeframe for the main character in her search for a new self. With the help of Baudelaire's and Virginia Woolf's concepts of flâneur and flâneuse, used by Vera Eliasova in her research, and Guy Debord's theory of psychogeography, this article explores how through wandering and circling along the streets of the city the heroine spots her own reflection in the city's many-sided face.

In this context, urban theory plays a significant role in providing migrant literature with an approach to the study of interrelations between a person and a place, which very often become a crucial force in the process of a migrant's selfidentification and assimilation. In such circumstances mental maps, which Kevin Lynch, an urban planner and an early proponent of the concept of mental mapping, understood as "the environmental image, the generalized picture of the exterior physical world that is held by an individual", ${ }^{5}$ help a newcomer discover an unknown location and obtain a skill of self-navigation. A place ceases to be unknown anymore and with the help of a mental map a person manages to set and adjust his/her mode of life according to the referential points of everyday movements and finally elaborates his/her own vision of a place. While in urban studies mental maps provide anyone from an architect to a city dweller with a visual form of a city, in literature they help to create a visual image through the verbal form and reveal those invisible connections which appear as a result of the experience of every inhabitant whose lasting interactions endow a city image with memories and meanings. Therefore Gin, the leading character of Gimme the Money, as a city observer becomes an inseparable part of the city image, because her vision of the city and her activities are as important as the stationary physical elements of New York. As an observer she plays an active role in perceiving the world and is involved in a creative process of developing her image of the city, because, as Kevin Lynch stated, "the environment suggests distinctions and relations, and the observer [...] - selects, organizes, and endows with meaning what he sees". ${ }^{6}$

\footnotetext{
${ }^{5}$ K. Lynch, The Image of the City, Cambridge, MA-London 1960, p. 4.

${ }^{6}$ Ibid., p. 6.
} 
At the very beginning of the novel, New York is unattainable for the leading character, who could not grasp the wholeness of the city, conceive its vastness and translate it into the city image. Gin's acquaintance with the city is cascading: starting from identifying New York with a big planet which emits gravity, moving down to meeting its districts, and finishing with cruising along its streets with the pervasive sense of belonging. At first Gin felt lost in the city and without a mental map New York "[...] seemed reserved and far-away [...] Gin sat by the window, drinking in the City with her eyes - the City into which she had arrived and still hasn't arrived [...]. The skyline of Manhattan lured her into itself with an enormous colorful Unknown". ${ }^{7}$ It is only later when Gin's mental map of the city gets legible and well structured that New York is not distant and detached anymore. From Kevin Lynch's point of view, the feeling of anxiety and even terror caused by the failure to orient in an unknown location and security and confidence an ordered image of the city gives reveal to us how closely they are linked to an individual's sense of balance and well-being. ${ }^{8}$ Concentrated on the fear of disorientation, a person perceives the surrounding environment as a potential threat, while a clear and distinctive image not only offers the sense of safety but also intensifies other human experiences. That is why the image of New York presented in the novel is constantly developing and changing. At the beginning of the novel, the city is depicted as a big planet which attracts people from all over the world because of its gravity which, of course, can be associated with the sense of belonging which people who migrated to New York had felt long before they arrived in the city. On the other hand, the symbol of a planet also suggests the illusionary image of the city, which exists in a form of a myth until someone gets a chance to meet New York in person. What happens afterwards when a romanticized idea of the city clashes with the reality of the actual place, which is far from its perfect but still imaginary prototype, is very similar to Gin's arrival in New York, which is shown as a painful and disillusioning accidental fall, which simply happened because Gin, although never planned to come to New York, always felt the connection with the city. In one of the chapters in order to describe a supernatural power of New York's attraction, Pekarkova uses the image of an octopus that with the help of tentacles tempts people to itself: "Big cities reach out their tentacles like huge octopuses, 'and' people let themselves be lured and attach themselves to these tentacles, as if they were umbilical cords". ${ }^{9}$ Later she uses the same image to show how Gin's perception of the world around has changed and how different her emotional state is from what she felt when she first arrived in the city: "[...] all over the surface of her body visual sensors sprouted like she was a rainworm. Tentacles emerged from her belly like she was an octopus, and their gentle suction cups stroked the whole world. The world stroked her back". ${ }^{10}$

Pekarkova's manner to involve Gin into the visual description of the city emphasizes their connection and interrelation; New York needs its residents to be-

\footnotetext{
${ }^{7}$ I. Pekarkova, Gimme the Money, London 2000, p. 11.

${ }^{8}$ K. Lynch, op. cit., p. 4.

${ }^{9}$ I. Pekarkova, op. cit., p. 1.

${ }^{10}$ Ibid., p. 19.
} 
come the city it is as well as its people need the city to shape their identities, which are determined by the links people create when they live and act in the world. In the natural way, New York determines the experience of its dwellers who, as Arto Haapala claims, familiarize themselves with their immediate location. ${ }^{11}$ In some way, Gin's rewriting and reinvention of the city through appropriation of New York's images, views, ambience and reflection of all these elements on her mental map of the city as well as complete involvement into its life through the act of driving across the city becomes the "place-making": 12 the way immigrants respond to alienation, isolation, and difference and try to redefine and settle their new identities, and create new places of belonging, comfort, and security. In such a way Gin becomes highly aware of her environment and describes the city with an absolute, even satnav precision, mentioning names of the streets and intersections, arches and bridges, parks and rivers, avenues and boulevards, tunnels and highways, turns and detours. And it seems that each time Gin names the elements of New York, she reestablishes connection with the city and appropriates it. The more places get reflected on her mental map, the less unknown and threatening New York looks to Gin and the stronger her sense of belonging grows. Although, absorbing new sensuous impacts, she is constantly discovering the city and updating her mental map, she manages to keep her basic image solid, filling the gaps with sensitive and emotional details which only touch upon many previous elements and present the image of the city more sharply and intensely to the readers. In such a way the audience rediscover the place together with Gin who not only creates a visual image of the city, but also endows it with personal experience and meaning.

Analysing the imagery of Gin's narration, Vera Eliasova defines dynamism and mobility as basic principles of the interaction between New York and the leading character. Because of the leading character's work, the relationship between New York and Gin develops at a different speed when she has only a half of a second to shoot a glance at a city's representation and imprint it on her mental map. Gimme the Money may even be called a literary map of the Big Apple, which by guiding readers through the chapters navigates them around the city and paints its sights with highly coloured words. It is its smells, hues, sounds, glances, touches, and speeds, which get reflected onto Gin's mental map and which become little blocks of the immense structure Gin is trying to apprehend and appropriate. Vera Eliasova also points out the never-ending movement of Gin's yellow cab which not only lets her "observe the City in ways that are both intimate and wide ranging", ${ }^{13}$ but also reminds of the infinity symbol and defines the circular character of their interaction: Gin and her New York exist at the same time, changing, defining, and absorbing each other; and within the circles where their identities overlap, Gin and the city will remain inseparable parts of each other's natures even when the time to part comes. The researcher also insists that the image of circles becomes

${ }^{11}$ A. Haapala, The Urban Identity: The City as a Place to Dwell, "Place and Location" 2003, III, p. 20.

${ }_{12}$ D. Phillips, D. Robinson, op. cit., p. 415.

13 V. Eliasova, op. cit., p. 643. 
symbolic in the novel; letting alone the visual representation of the dynamic life in the megalopolis, which is suggested in the titles of such chapters as "Protective Circles", "The City, Circles", "Cobwebs", "Return Trips", it also refers to the immigrant identity as to the subject of "constant reimagination"14 and embodies the repetitiveness "of Gin's writing of the self" ${ }^{15}$ The cruise around the city becomes the key to the heroine's complex inner world and a crucial means in her search for the self. By learning the city and decoding its signs, Gin finally manages to set the route to herself; at the end of the book she knows what she really wants and is not afraid to follow her heart, although the author implies that "there is no such final 'discovery' and being a 'stranger' is a persistent state of identity" ${ }^{16}$. In the researcher's opinion, the metaphor of circles also denotes the author's attempt to create a new type of the immigrant story - "nonlinear", "open to chance", ${ }^{17}$ and detached from the past and the future. That is why Gimme the Money is an openended story, which accentuates the present tense and "is always in making". ${ }^{18}$ Gin does not talk about her past and refuses to explain her history. There are only few moments in the book when her Czech origin is mentioned:

Gin's thick, unmistakable and ungotten-riddable-of Slavic accent that took Gin out $[\ldots]^{19}$

A black man. Don't teach this here missy bad words like that. This here missy, she don't know words like that. She's from Czescoslowakia. ${ }^{20}$

You're [...] from Europe. Cause you are [...] Czecoslavian [...] Yugoslovakian [...] what is it that you said? ${ }^{21}$

He was touching that old appendectomy scar which the doctors back in Czechoslovakia had lousily sewn up with seven stitches. ${ }^{22}$

She does not make plans either. And by doing so, Gin concentrates on solving the relevant everyday issues which distract her from constant thinking about her past and future and, as Madelaine Hron believes, give her the chance to have "a fresh outlook on things", ${ }^{23}$ which is devoid of nostalgic digressions, and live in the moment, because, as Iva Pekarkova sees it, this is the only way for Gin to fully integrate into her new environment. Sladja Blazan rightly notices that Gin liberates herself from the necessity of being a Czech immigrant and in such a way gets a chance to be accepted and heard ${ }^{24}$ New York becomes her present where she finds her friends, her family, her love and meaning. And if in the beginning

${ }^{14}$ Ibid., p. 649.

15 Ibid.

${ }^{16}$ Ibid., p. 650.

17 Ibid.

${ }^{18}$ Ibid.

${ }_{19}$ I. Pekarkovaop. cit., p. 27.

${ }^{20}$ Ibid., p. 129.

${ }^{21}$ Ibid., p. 229.

22 Ibid., p. 278.

${ }^{23}$ M. Hron, Jumping into Another Life: An Interview with Iva Pekarkova, "Central Europe Review" CER Archive, Vol 3, No. 15, http://www.ce-review.org/01/15/books15_hron2.html (access: 15.05.2019).

${ }^{24}$ S. Blazan, Urban Dwellers: Women Writers Who Left Eastern Europe Never to Arrive in the United States, “American Studies" 2008, 53 (2,) p. 197. 
she comes to the city as a "clean slate", ${ }^{25}$ in the end Gin leaves the city with some store of experience and knowledge.

However, Vera Eliasova claims that "[...] the ideal of the baggage-free state of mind should not be dismissed altogether. Rendering Gin as living without history enables Pekarkova to revise the stereotype of the immigrant full of Old World tradition and history", ${ }^{26}$ which means that the author "tries to reconceive the immigrant as someone who 'belongs' to the New World unequivocally", ${ }^{27}$

$[\ldots]$ she felt she belonged [...] to something, to the secret brotherhood of blue distances perhaps, to the brotherhood of those who dared. ${ }^{28}$

Gin BELONGED, and even though Gin's English was simply funny to listen to, Gloria couldn't help herself; she had to envy her her lack of knowledge of the New York world $[\ldots]$ and Gin's naivety $[\ldots]$ which made it possible for her to regard the whole colorful palette THE WAY IT WAS, without any prejudice. ${ }^{29}$

Gin's sense of belonging is closely related to her vision of herself as a part of the city and her acceptance of the city's nature and rules, so calling it home means being a part of the community, where its members speak the same language, live in the same circumstances, see the same city at the same speed, and share the same present. Their previous background stays outside of the community because it involves differences. For the same reason, Gin speaks English, gets married twice in order to get a Green Card, and does not use her Czech name; she has the same problems and pursues the same goals as other immigrants do so, by sharing the attributes of the community, Gin eliminates her differences, appropriates the city and becomes its part. By showing the reciprocal connection between of the urban identity of New York and its dwellers, Iva Pekarkova, manages to construct complex multi-layered space which, on the one hand, is fixed and objective, but on the other hand, is changeable and subjective. In Chapter 12 "Art, City" where she pays attention to the tiniest signs of people's presence in the city such as "pink, white, blue and light chewing gums trampled into the asphalt of the streets" or "the windows of abandoned buildings", "lost shoes strings and buttons and bags" ${ }^{30}$ as acts of art, the unique peculiarities that create the beauty of the city and its charm, the author also compares Gin to an artist who by "working day after day on a humongous canvas - the Manhattan Island - was creating yellow pictures on it with jerky motions of her brush"31 and was leaving her imprint with her tires stroking the surface of the city. But at the same time, as Vera Eliasova claims, "Instead of gliding on the surface of the city, Gin 'becomes' the city as she goes into its depth, 'forced deep into the asphalt' which symbolizes the primal matter of the city". ${ }^{32}$ In this context, Gin and her cab become "a building block, a cell, a molecule in that humongous,

\footnotetext{
${ }^{25}$ M. Hron, op. cit.

${ }^{26}$ V. Eliasova, op. cit., p. 646.

27 Ibid.

${ }^{28}$ I. Pekarkova, op. cit., p. 19.

${ }^{29}$ Ibid., p. 27.

${ }^{30}$ Ibid., p. 61.

${ }^{31}$ Ibid., p. 63.

32 V. Eliasova, op. cit., p. 659.
} 
colorful, crazy mosaic" of the city which "has a heart" 33 and "she was teaching her own heart to beat the same way. [...] She chopped her whole life into segments defined by the heartbeat of that City". ${ }^{34}$ As we read in Arto Haapala's article "The Urban Identity: The City as a Place to Dwell", "The identity of the city bears on the identity of those living in it, and vice versa: the urban environment reflects human needs and values". ${ }^{35}$ In other words, the image of the city, which is seen and experienced through the prism of gender, ethnicity, age, and migrant status, ${ }^{36}$ also influences individual perception of its dwellers and the constant interaction between the city and its people leads to mutual changes when identities of the city and its inhabitants are permanently redefining each other.

The overlapping of identities of a place and its residents, who, by perceiving urban reality, transform the context of the metropolis in a double image, internal and external, coincides with the idea of flâneur. The concept, firstly profoundly explored by Charles Baudelaire in his writings, presents the casual wanderer and reporter of street-life in the modern city, whose sensitive observations of an urban environment define his emotional state and shape his understanding of the world around. As a narrator of an everyday experience, who through looking at and listening to the kaleidoscopic manifestations of the life in a city space, the flâneur investigates the impact of city life on the human self-perception or, as Christopher Butler suggests, through wandering and strolling around the city without any particular purpose, the flâneur is trying to achieve a form of transcendence:

[...] the city's modernity is most particularly defined for him by the activities of the flâneur observer, whose aim is to derive 'l'éternel du transitoire' ('the eternal from the transitory') and to see the 'poétique dans l'historique'('the poetic in the historic'). ${ }^{37}$

In this case, a city, according to Deborah L. Parsons, represents "a constituent of identity" 38 whose experience of urban space is translated into a narrative form.

We can look at the flâneur as a figure that allows the showing of a variety of fragments of daily life from a sensorial and sensitive way. In fact, in an approach on the lived experience, the flâneur is the sign of a modality that informs us of the way humans feel, perceive, detect, and express a space and its symbolic significance..$^{39}$

He [flâneur] uses the space with his body and conscience and in this way composes a construction of senses, allowing an understanding of the collective spaces through daily construction of directions and relations. ${ }^{40}$

As a literary method, flânerie (the art of strolling and looking) helps to decode and make sense of urban experience. While Baudelaire saw the flâneur as having

${ }^{33}$ I. Pekarkova, op. cit., p. 34.

${ }^{34}$ Ibid., p. 245.

${ }^{35}$ A. Haapala, op. cit., p. 13.

${ }^{36}$ D. Phillips, D. Robinson, op. cit., p. 410.

${ }^{37}$ C. Butler, Early Modernism: Literature, Music and Painting in Europe 1900-1916, New York 1994, p. 133.

${ }^{38}$ D.L. Parsons, Streetwalking the Metropolis: Women, the City, and Modernity, Oxford 2000, p. 7.

${ }^{39}$ F. La Rocca, A Theoretical Approach to the Flaneur and the Sensitive Perception of the Metropolis, "Sociétés" 2017, №135 (1), pp. 10-11.

${ }^{40}$ Ibid., p. 12. 
a key role in understanding and portraying the city, later theorists such as Georg Simmel or Walter Benjamin analysed the urban experience in more sociological and psychological terms. They believed that modern city was transforming identities of those who inhabited it by giving them a new relationship to time and space and by shifting fundamental notions of freedom and being. ${ }^{41}$ They also believed that it was exclusively a male prerogative to be a figure with time and money who could allow himself to amble around the city at will and at the same time to be involved in and separate from the urban performance. As we read in Lauren Elkin's

A tribute to Female Flâneurs: the Women Who Reclaimed Our City Streets, [...] for as long as there have been cities, there have been women living in them, yet if we want to know what it's like to walk thoughtfully in the city, there is only a long tradition of writing by men that tells us [...]. But there have always been women writing about cities, chronicling their lives, telling stories, taking pictures, making films, engaging with the city any way they can. ${ }^{42}$

The only requirement the genre imposes on a female counterpart of the flâneur, according to Lauren Elkin, is simply being a walker, "who gets to know the city by wandering its streets, investigating its dark corners, peering behind façades, penetrating into secret courtyards". ${ }^{43}$ Virginia Woolf described this activity in a similar way. By calling it "street haunting" she insisted that flânerie makes women leave the things that define their identities at home, and become casual anonymous passerby on the streets of a city, who instead of just reacting to the cityscape start interacting with the urban space changing it and at the same time being changed by it. ${ }^{44}$ In this respect, as Vera Eliasova claims, Viginia Woolf and Iva Pekarkova have similar understanding of the city's role as an essential influence on female subjectivity. ${ }^{45}$ Moreover, both authors see the city as a place of chances and encounters, which inevitably - no matter how much time it may take - bring a character to a significant discovery of a new self. Obviously, the flâneuse Woolf and Pekarkova portrayed in their texts is different in terms of historical period, worldview, and life situation, but their vision of a woman as an active figure of an urban space and a valuable and careful observer of a city spectacle, bring their literary esthetics together.

Dynamism and mobility, defined by Vera Eliasova as central notions of the interaction between Gin and New York, distinguish a modern flâneur, who very often encounters a home city or experiences a temporary dislocation through walking, from a postmodern flâneuse, who "travels continents and whose sense of dislocation is persistent". ${ }^{46}$ Moreover, as Eliasova points out, the speed and

${ }^{41}$ G. Simmel, The Metropolis and Mental Life [in:] The Sociology of Georg Simmel, ed. K.H. Wolff, New York 1950, pp. 409-424.

${ }^{42}$ L. Elkin, A Tribute to Female Flâneurs: The Women Who Reclaimed Our City Streets, "The Guardian", https://www.theguardian.com/cities/2016/jul/29/female-flaneur-women-reclaim-streets (access: 22.05.2019).

${ }^{43}$ Ibid.

${ }^{44}$ V. Woolf, Street Haunting, San Francisco 1930, p. 5.

${ }^{45}$ V. Eliasova, op. cit., p. 652.

${ }^{46}$ Ibid., p. 653. 
the mobility of a postmodern flâneuse is different: while a modern flâneur walks along the streets, Gin drives a cab, ${ }^{47}$ which not only becomes the primary means of visualization and exploration of the city space, but also a tool for the leading character to modify the city image. Stefanie Weymann-Teschke claims that Gin "as one of the few female taxi drivers in New York City, engages in a form of motorized flânerie": ${ }^{48}$ the invisibility of the driver and private space that a cab provides Gin with puts her in a unique position of an everyday observer who although is present in the city image is at the same time as if removed from it and absent for passerby on a street. Thus, as the flâneuse she observes the city in her own rhythm - which coincides with the city's rhythm - from inside the car Gin is able to bring life to the ordinary details, and discover the city to the readers in the deepest way. Gin is not ashamed to lift the veil of privacy and lets the audience into her territory as if welcoming them as passengers into her yellow cab. So by having a literary ride with Gin, readers discover her secrets, accompany her in the most troublesome and stressful situations, hold their breath at moments of intimacy, and, finally, get a chance to see the city through her eyes and meet her New York. Every day Gin gets a chance to see the city anew, rediscover the place and its inhabitants often in simple but striking ways. For instance, "the uppitymellow lifting of the left arm" of ladies whose "right hand is holding a leash with a choking lap-sized dog" become an identifier of Madison Avenue and "the wellpracticed wave of the stockbrokers and bond traders" denote the area near the World Trade Center or on Wall Street. ${ }^{49}$ She also gets a possibility to learn more about herself, because her yellow cab turns out to be not only a hard shell for her fragile inner world but also a connector which establishes a strong bond between Gin and the city. As Mimi Sheller puts it, a car

$[\ldots]$ transforms the way we sense the world and the capacities of human bodies to interact with that world through the visual, aural, olfactory, interoceptive and proprioceptive senses. We not only feel the car, but we feel through the car and with the car. ${ }^{50}$

In such a way, Pekarkova changes a cab, a postmodern means of the exploration of the city, into the part of the urban landscape where the heroine's psychological experience of the city reveals her constant self-negotiation and reimagination.

Psychogeography, as an allied approach to the concepts of mental maps and flânerie, also studies the mutual relations between a city and its dwellers, but from a slightly different perspective. Defined by Guy Debord as "specific effects of the geographical environment, consciously organized or not, on the emotions and behaviour of individuals" ${ }^{\prime 1}$, psychogeography focuses on the psychological effects of an urban environment on its inhabitants. In his Theory of Dérive, the

${ }^{47}$ Ibid.

${ }^{48}$ S. Weymann-Teschke, op. cit., p. 18.

${ }^{49}$ I. Pekarkova, op. cit., p. 47.

${ }^{50}$ M. Sheller, Automative Emotions: Feeling the Car, "Theory Culture \& Society" 2004, Vol. 21, No. 4-5, p. 228.

${ }^{51}$ G.-E. Debord, Introduction to a Critique of Urban Geography, "The Situationist International Text Library", http://library.nothingness.org/articles/SI/en/display/2 (access: 23.05.2019). 
researcher, investigates a particular way of interacting with urban space, when a walker, attracted by the sensory experiences a place offers as if delves into their exploration without any particular reason. Any turn, crossing or even dead end are treated as a promising possibility, a chance to discover something new and saturate the image of a place with new shades of emotional experiences. In this respect, Gimme the Money provides a very illustrative literary representation of what Debord understood as the dérive, when Gin's constant movement across New York, full of opportunities and unexpected discoveries, is seen as a sequence of variable combinations which in the end bring the leading character to an accidental and at the same time unique find:

Chances were chained one after the other - and Gin was painfully aware that with every YES she loses a NO, with every RIGHT TURN she loses a LEFT TURN or KEEP GOING STRAIGHT, that behind every chance there is a whole mob of other chances hiding, chances that had escaped Gin forever. ${ }^{52}$

In her analysis of the psychogeographic features of the novel, Weymann-Teschke states that "it is the haphazardness of driving through the city that Gimme the Money banks on to produce an intensely visual experience of urban space"53. By showing Gin's emotional exploration of New York, Iva Pekarkova proves that the process of what Phillips and Robinson called the "place-making" 54 cannot be purely rational. Its fortuitousness, unpredictability, and impossibility to be everywhere at the same time play a crucial role in finding Gin's own path in this "enormous colorful Unknown". ${ }^{55}$ In the end, random finds will lead her to another unexpected discovery - her new self, when the most urgent answers to the most complicated questions can be simply put in one sentence without any pretext and the road to herself will not be twisting and uncertain anymore. The result of such haphazard interaction between Gin and New York is an emotional map of the city, which is rather attached to her impressions related to the particular place than to the place itself. For example, East Village, the center of artistic life and the habitat of the creative community, for Gin will always symbolize the contradiction between art and reality, belonging and alienation. Midtown, "the epicenter of movement, a place of transition and transfer", ${ }^{56}$ will be associated with work, two taxi garages, yellow strokes Gin's cab leaves on the city's image, and colourful and rhythmic reflections of New York.

Gin's numerous interactions with people also play an important role in her emotional exploration of New York. Cruising around the city, she not only transports passengers from one place to another, but, by being the part of their journey, she also saturates her image of the city with somebody's memories, emotions, experiences, which become hers, and get saved in her hard drive and get reflected on her mental map. Therefore in her head the image of New York originates from individual and collective perspectives which merge into one big concept of the City:

\footnotetext{
52 I. Pekarkova, op. cit., p. 63.

53 S. Weymann-Teschke, op. cit., p. 235.

54 D. Phillips, D. Robinson, op. cit., p. 415.

55 I. Pekarkova, op. cit., p. 11.

56 S. Weymann-Teschke, op. cit., p. 241.
} 
The interference of thoughts, opinions, ideas and heads, however, penetrated through the entire City. ALL the heads here left their signatures on one another; all the opinions, loves, hates, happy and unhappy thoughts, ideas, emotions, inspirations - absolutely everything that ever took place in human heads got reflected in the heads of all the others $[\ldots] .{ }^{57}$

And even though Gin might not share the same view on things, she will associate Manhattan with plastic and dirt and see Harlem as a place which "carries all the terror that white men feel from it". ${ }^{58}$ Without experiencing all the situations stored in her head but though sharing and exchanging them with other inhabitants, Gin entwines them into her canvas of memories, faces, and signs and projects them on her image of the city.

Iva Pekarkova's Gimme the Money is an exemplary novel of a new approach to the migrant literature, which questions conventional thinking about a migrant identity and presents a new type of a character, who, instead of describing the way from an old home to a new one, is in constant moving from her old self to the new one. The locality becomes extremely important in the text, because through the relationship between the leading character and New York Gin can reimagine herself and embrace the changes their interaction with the city caused. By portraying New York as a place, which has both physical and symbolic attributes, the author not only creates the background setting for the story, but also manages to project the leading character's thoughts onto its streets. By identifying the heroine with the city, Pekarkova emphasizes their connection and presents her understanding of the idea of belonging: she makes Gin become the city and vice versa. With the help of such theoretical concepts as mental maps, flânerie and psychogeography the author shows how the leading character manages to spot her own reflection in multifarious New York, find her own place in it and appropriate the urban environment and by using symbolic, visceral, and haptic imagery, Pekarkova proves that reciprocity, similarity, dynamism and mobility are the basic principles of the interaction between Gin and the city. From this perspective, Gimme the Money is a vivid migrant writing which takes us close to the street and to the leading character, who is portrayed, as psychogeographers would say, like a romantic flâneuse, but with a cab and quite postmodern vision of life.

\section{Bibliography}

\section{Primary sources}

Pekarkova I., Gimme the Money, London 2000.

\section{Secondary sources}

Blazan S., Urban Dwellers: Women Writers Who Left Eastern Europe Never to Arrive in the United States, "American Studies" 2008, 53 (2), pp. 189-208.

Butler C., Early Modernism: Literature, Music and Painting in Europe 1900-1916, New York 1994.

\footnotetext{
${ }^{57}$ I. Pekarkova, op. cit., p. 33.

${ }^{58}$ Ibid., p. 86.
} 
Debord G.-E., Introduction to a Critique of Urban Geography, "The Situationist International Text Library", http://library.nothingness.org/articles/SI/en/display/2 (access: 23.05.2019).

Debord G.-E., Theory of the Dérive. "Situationist International Online", https://www. cddc.vt.edu/sionline/si/theory.html (access: 23.05.2019)

Eliasova V., A Cab of Her Own: Immigration and Mobility in Iva Pekarkova's Gimme the Money, "Contemporary Literature" 2006, 47 (4), pp. 636-668.

Elkin L., A Tribute to Female Flâneurs: The Women Who Reclaimed Our City Streets, "The Guardian", https://www.theguardian.com/cities/2016/jul/29/female-flaneur-women-reclaim-streets (access: 22.05.2019).

Foner N., New York: A Unique Immigrant City, Newsletter of the American Sociological Association, http://www.asanet.org/sites/default/files/savvy/footnotes/indexone.html (access: 11.03.2019).

Haapala A., The Urban Identity: The City as a Place to Dwell, "Place and Location" 2003, III, pp. 13-24.

Hron M., Jumping into Another Life: An Interview with Iva Pekarkova, "Central Europe Review" CER Archive, Vol. 3, No. 15, http://www.ce-review.org/01/15/ books15 hron2.html (access: 15.05.2019).

La Rocca F., A Theoretical Approach to the Flâneur and the Sensitive Perception of the Metropolis, "Sociétés" 2017, No 135 (1), pp. 9-17.

Lynch K., The Image of the City, Cambridge, MA-London 1960.

NYC Mayor's Office of Immigrant Affairs, State of Our Immigrant City: Annual Report, NYC Mayor's Office of Immigrant Affairs, https://www1.nyc.gov/assets/immigrants/downloads/pdf/moia_annual_report\%202019_final.pdf (access: 13.03.2019).

Parsons D.L., Streetwalking the Metropolis: Women, the City, and Modernity, Oxford 2000.

Phillips D., Robinson D., Reflection on Migration, Community, and Place, "Population, Space and Place" 2003, Vol. 21 (5), pp. 409-420.

Sheller M., Automative Emotions: Feeling the Car, "Theory Culture \& Society" 2004, Vol. 21, No. 4-5, pp. 221-242.

Simmel G., The Metropolis and Mental Life [in:] The Sociology of Georg Simmel, ed. K.H. Wolff, New York 1950, pp. 409-424.

Weymann-Teschke S., The City as Performance: The Contemporary American Novel and the Power of the Senses, Heidelberg 2018.

Woolf V., Street Haunting, San Francisco 1930. 